\title{
PEMANFAATAN MEDIA PROYEKTOR UNTUK MENINGKATKAN PRESTASI BELAJAR SISWA KELAS VIII MATA PELAJARAN BK-TIK TAHUN PELAJARAN 2019 - 2020
}

\begin{abstract}
Mat Ali
SMP Negeri 1 Sekaran

INFO ARTIKEL

Diterima:28-1-2020

Disetujui:5-2-2020

Abstrak: Penelitian ini bertujuan untuk meningkatkan prestasi belajar dan penguasaan materi pelajaran BK-TIK siswa kelas VIII SMP Negeri 1 Sekaran. Penelitian ini termasuk dalam penelitian tindakan kelas. Di mana kegiatan perbaikan dilakukan sebanyak tiga siklus. Data yang diperoleh dari

Kata Kunci:

Media Proyektor,

Prestasi Belajar, BK-

TIK penelitian ini berupa peningkatan prestasi dan penguasaan materi BK_TIK siswa dengan pemanfaatan media proyektor dan hasil belajar siswa dengan penggunaan media proyektor. Data penelitian diperoleh dengan menggunakan lembar observasi dan tes formatif. Dari penelitian yang telah dilakukan diperoleh data bahwa pemanfaatan media proyektor dapat memberikan pengaruh positif terhadap hasil belajar siswa. Hal ini dapat dilihat dari semakin meningkatnya pemahaman dan penguasaan siswa terhadap materi yang telah disampaikan guru selama ini (ketuntasan belajar meningkat dari siklus I, II, dan III) yaitu masing-masing $55 \%, 70 \%$, dan $90 \%$. Pada siklus III ketuntasan belajar siswa secara klasikal telah tercapai. Selain itu, model pembelajaran dengan memanfaatkan media proyektor dapat dijadikan sebagai salah satu media alternatif belajar.
\end{abstract}

\begin{abstract}
This study aims to improve learning achievement and mastery of BK-ICT subject material for eighth grade students of SMP Negeri 1 Sekaran. This research is included in class action research. Where the improvement activities carried out as many as three cycles. Data obtained from this study in the form of increased achievement and mastery of students BK_TIK material by using projector media and student learning outcomes using projector media. Research data were obtained using observation sheets and formative tests. From the research that has been done, it is obtained data that the use of projector media can have a positive influence on student learning outcomes. This can be seen from the increasing understanding and mastery of students on the material that has been delivered by the teacher so far (mastery learning increases from cycles I, II, and III), each of which are $55 \%, 70 \%$, and $90 \%$. In cycle III students' classical learning completeness has been achieved. In addition, the learning model using projector media can be used as an alternative learning media.
\end{abstract}

Alamat Korespondensi:

SMP Negeri 1 Sekaran, Kab. Lamongan, Jawa Timur, Indonesia

Kudikan, Kec. Sekaran, Kab. Lamongan

Surel: matalipaba@gmail.com 
Pembangunan Nasional di bidang pengembangan sumberdaya manusia Indonesia yang berkualitas melalui pendidikan merupakan upaya yang sungguhsungguh dan terus-menerus dilakukan untuk mewujudkan manusia Indonesia seutuhnya. Sumberdaya yang berkualitas akan menentukan mutu kehidupan pribadi, masyarakat, dan bangsa dalam rangka mengantisipasi, mengatasi persoalan-persoalan, dan tantangan-tantangan yang terjadi dalam masyarakat pada kini dan masa depan.

Pekerjaan mewujudkan maksud di atas bukan hal yang mudah dan sederhana.Tidak pula dapat dicapai dalam waktu singkat.Hal itu memerlukan dukungan seluruh komponen bangsa dan usaha yang direncanakan secara matang, berkelanjutan, serta berlangsung seumur hidup.Ini berarti bahwa untuk menciptakan manusia Indonesia yang utuh dan berkualitas melalui pendidikan dibutuhkan seperangkat prasarana dan sarana pendukujjjjng yang memadai.Dalam sistem pendidikan, kurikulum merupakan komponen esensial dan utama yang perlu mendapat perhatian dari berbagai pihak, seperti pemerintah, pengembangan kurikulum, dan para guru sebagai ujung tombak pelaksanaan kurikulum dimaksud.

Salah satu permasalahan yang dihadapi oleh bangsa Indonesia adalah rendahnya mutu pendidikan, khususnya pendidikan dasar dan menengah. Berbagai usaha telah dilakukan untuk menigkatkan mutu pendidikan nasional, antara lain melalui berbagai pelatihan dan peningkatan kualitas guru, penyempurnaan kurikulum, pengadaan buku dan alat pelajaran, perbaikan sarana dan prasarana pendidikan lain, dan peningkatan mutu manajemen sekolah, namun demikian, berbagai indikator mutu pendidikan belum menunjukkan peningkatan yang memadai.

Upaya peningkatan kualitas pendidikan di Indonesia tidak pernah berhenti.Berbagai terobosan baru terus dilakukan oleh pemerintah melalui Depdiknas. Upaya itu antara lain dalam pengelolaan sekolah, peningkatan sumber daya tenaga pendidikan, pengembangan/penulisan materi ajar, erta pengembangan paradigma baru dengan metodologi pengajaran.

Mengajar bukan semata persoalan menceritakan.Belajar bukanlah konsekuensi otomatis dari perenungan informasi ke dalam benak siswa.Belajar memerlukan keterlibatan mental dan kerja siswa sendiri. Penjelasan dan pemeragaan semata tidak akan membuahkan hasil belajar yang langgeng. Yang bisa membuahkan hasil belajar yang langgeng hanyalah kegiatan belajar aktif.

Apa yang menjadikan belajar aktif? Agar belajar menjadi aktif siswa harus mengerjakan banyak sekali tugas. Mereka harus menggunakan otak, mengkaji gagasan, memecahkan masalah, dan menerapkan apa yang mereka pelajari. Belajar akif harus gesit, menyenangkan, bersemangat dan penuh gairah. Siswa bahkan sering meninggalkan tempat duduk mereka, bergerak leluasa dan berfikir keras (moving about dan thinking aloud)

Untuk bisa mempelajari sesuatu dengan baik, kita perlu mendengar, melihat, mengajukan pertanyaan tentangnya, dan membahasnya dengan orang lain. Bukan Cuma itu, siswa perlu "mengerjakannya", yakni menggambarkan sesuatu dengan cara mereka sendiri, menunjukkan contohnya, mencoba mempraktekkan keterampilan, dan mengerjakan tugas yang menuntut pengetahuan yang telah atau harus mereka dapatkan.

Proses pembelajaran Mata Pelajaran Teknologi Informasi dan Komunikasi (TIK) cenderung lebih banyak menggunakan tempat di laboratorium komputer daripada di dalam ruang kelas. Agar pembelajaran TIK di ruang laboratorium komputer menjadi pembelajaran yang aktif, kreatif dan menyenangkan, maka perlu dipilih media yang tepat yang dapat digunakan dalam ruang laboratorium komputer, sehingga tujuan pembelajaran yang diharapkan dapat mudah tercapai. Maka penulis perlu mengadakan penelitian tindakan kelas dengan judul 
KARANGAN: Jurnal Kependidikan, Pembelajaran, dan Pengembangan, Vol 02, No 01, Bln Feb, Tahun 2020, Hal 21 - 31

Pemanfaatan Media Proyektor di Laboratorium Komputer Dalam Membimbing Siswa Kelas VIIIB Mengenai Cara Membuat diagram Menggunakan Program Pengolah angka (Microsoft exel ) pada semester genap tahun pelajaran 2019/2020.

\section{METODE}

Penelitian ini merupakan penelitian tindakan (action research), karena penelitian dilakukan untuk memecahkan masalah pembelajaran di labolatorium komputer.Penelitian ini juga termasuk penelitian deskriptif, sebab menggambarkan bagaimana suatu teknik pembelajaran diterapkan dan bagaimana hasil yang diinginkan dapat dicapai.

Menurut Oja dan Sumarjan (dalam Titik Sugiarti, 1997: 8) mengelompokkan penelitian tindakan menjadi empat macam yaitu, (a) guru sebagai peneliti; (b) penelitian tindakan kolaboratif; (c) simultan terintegratif; (d) administrasi social eksperimental.

Dalam penelitian tindakan ini menggunakan bentuk guru sebagai peneliti, penanggung jawab penuh penelitian ini adalah guru.Tujuan utama dari penelitian tindakan ini adalah untuk meningkatkan hasil pembelajaran di kelas dimana guru secara penuh terlibat dalam penelitian mulai dari perencanaan, tindakan, pengamatan, dan refleksi.

Dalam penelitian ini peneliti tidak bekerjasama dengan siapapun, kehadiran peneliti sebagai guru di kelas sebagai pengajar tetap dan dilakukan seperti biasa, sehingga siswa tidak tahu kalau diteliti. Dengan cara ini diharapkan didapatkan data yang seobjektif mungkin demi kevalidan data yang diperlukan.

\section{Tempat, Waktu dan Subyek Penelitian}

Tempat penelitian adalah tempat yang digunakan dalam melakukan penelitian untuk memperoleh data yang diinginkan. Penelitian ini bertempat di Labolatorium Komputer SMP Negeri 1 Sekaran Semester genap Tahun Pelajaran 2019/2020. Waktu penelitian adalah waktu berlangsungnya penelitian atau saat penelitian ini dilangsungkan. Penelitian ini dilaksanakan pada bulan Januari semester genap tahun pelajaran 2019/2020. Subyek penelitian adalah siswa-siswi Kelas VIII D SMP Negeri 1 Sekaran Tahun Pelajaran 2019/2020 Pada pokok bahasan Membuat chart/grafik pada program pengola angka ( Microsoft Exel)

\section{Rancangan Penelitian}

Penelitian ini menggunakan Penelitian Tindakan Kelas (PTK). Menurut Tim Pelatih Proyek PGSM, PTK adalah suatu bentuk kajian yang bersifat reflektif oleh pelaku tindakan yang dilakukan untuk meningkatkan kemantapan rasional dari tindakan mereka dalam melaksanakan tugas, memperdalam pemahaman terhadap tindakan-tindakan yang dilakukan itu, serta memperbaiki kondisi dimana praktek pembelajaran tersebut dilakukan (dalam Mukhlis, 2003: 3).

Sedangkah menurut Mukhlis (2003: 5) PTK adalah suatu bentuk kajian yang bersifat sistematis reflektif oleh pelaku tindakan untuk memperbaiki kondisi pembelajaran yang dilakukan. Adapun tujuan utama dari PTK adalah untuk memperbaiki/meningkatkan pratek pembelajaran secara berkesinambungan, sedangkan tujuan penyertaannya adalah menumbuhkan budaya meneliti di kalangan guru (Mukhlis, 2003: 5). Sesuai dengan jenis penelitian yang dipilih, yaitu penelitian tindakan, maka penelitian ini menggunakan model penelitian tindakan dari Kemmis dan Taggart (dalam Sugiarti, 1997: 6), yaitu berbentuk spiral dari sklus yang satu ke siklus yang berikutnya. Setiap siklus meliputi planning (rencana), action (tindakan), observation (pengamatan), dan reflection 
(refleksi).Langkah pada siklus berikutnya adalah perncanaan yang sudah direvisi, tindakan, pengamatan, dan refleksi.Sebelum masuk pada siklus 1 dilakukan tindakan pendahuluan yang berupa identifikasi permasalahan. Siklus spiral dari tahap-tahap penelitian tindakan kelas dapat dilihat pada gambar berikut.

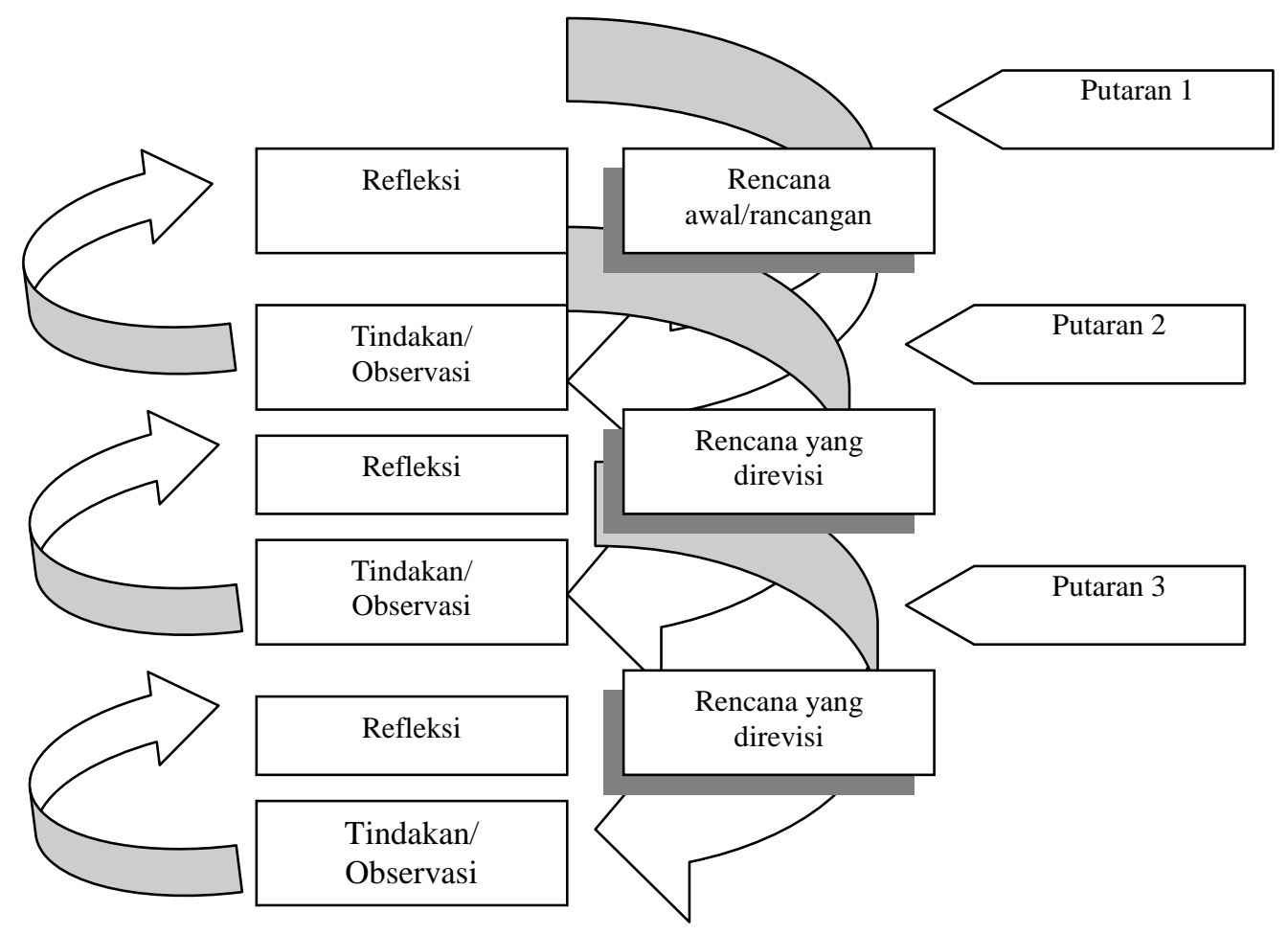

\section{dan Metode Pengumpulan Data}

Instrumen yang digunakan dalam penelitian ini terdiri dari: Silabus, Rencana Pelajaran (RP), Tes formatif dan unjuk kerja. Data-data yang diperlukan dalam penelitian ini diperoleh melalui observasi, format penilaian (tes objektif) dan format penilaian (tes unjuk kerja) .

\section{Teknik Analisis Data}

Untuk mengetahui keefektivan suatu metode atau penggunaan Media Pembelajaran dalam kegiatan pembelajaran perlu diadakan analisa data. Pada penelitian ini menggunakan teknik analisis deskriptif kualitatif, yaitu suatu metode penelitian yang bersifat menggambarkan kenyataan atau fakta sesuai dengan data yang diperoleh dengan tujuan untuk mengetahui prestasi belajar yang dicapai siswa juga untuk memperoleh respon siswa terhadap kegiatan pembelajaran serta aktivitas siswa selama proses pembelajaran.

Untuk mengalisis tingkat keberhasilan atau persentase keberhasilan siswa setelah proses belajar mengajar setiap putarannya dilakukan dengan cara memberikan evaluasi berupa soal tes tertulis dan unjuk kerja pada setiap akhir putaran. Analisis ini dihitung dengan menggunakan statistik sederhana yaitu:

\section{Format penilaian tes obyektif}

Tes obyektif ini adalah merangkum langkah-langkah pada tes unjuk kerja secara tertulis

Soal $1 \longrightarrow$ nilai $\max =10$

Soal $2 \longrightarrow$ nilai $\max =10$ 
KARANGAN: Jurnal Kependidikan, Pembelajaran, dan Pengembangan, Vol 02, No 01, Bln Feb, Tahun 2020, Hal 21 - 31

Soal $3 \longrightarrow$ nilai $\max =15$
Soal $4 \longrightarrow$ nilai max $=15$
Soal $5 \longrightarrow$ nilai max $=15$
Soal $6 \longrightarrow$ nilai max $=15$

Dengan : $\mathrm{Xb}=$ nilai yang diperoleh siswa pada tes obyektif

$\sum X=$ Jumlah skor yang diperoleh

$\sum X \max =$ Jumlah skor $\max (120)$

Format pada penilaian unjuk kerja

Soal $1 \longrightarrow$ nilai $\max =10$

Soal $2 \longrightarrow$ nilai $\max =10$

Soal $3 \longrightarrow$ nilai $\max =15$

Soal $4 \longrightarrow$ nilai $\max =15$

Soal $5 \longrightarrow$ nilai $\max =15$

Soal $6 \longrightarrow$ nilai $\max =15$

$\mathbf{X b}=\frac{\sum X}{\sum X \max } x 100$

Dengan $: X b=$ nilai yang diperoleh siswa pada tes unjuk kerja

$\sum X=$ Jumlah skor yang diperoleh

$\sum X \max =$ Jumlah skor $\max (80)$

Nilai yang diambil sebagai data dirumuskan sbb:

$X c=\frac{X a+X b}{2}$

$\bar{X} c=\frac{\sum X c}{\sum N}$

dengan $: X c=$ Nilai akhir yang diperoleh siswa

$\bar{X} c=$ Nilai rata rata siswa

$\sum X c=$ Jumlah nilai siswa

$\sum N=$ Jumlah siswa

\section{Untuk ketuntasan belajar}

Ada dua kategori ketuntasan belajar yaitu secara perorangan dan secara klasikal. Berdasarkan pedoman pelaksanaan belajar mengajar mata pelajaran BKTIK / Informatika di SMP Negeri 1 Sekaran, yaitu seorang siswa telah tuntas belajar bila telah mencapai skor $68 \%$ atau nilai 68 , dan kelas disebut tuntas belajar bila di kelas tersebut terdapat $85 \%$ yang telah mencapai daya serap lebih dari atau sama dengan $68 \%$. Untuk menghitung persentase ketuntasan belajar digunakan rumus sebagai berikut:

$$
P=\frac{\sum \text { Siswa.yang.tuntas.belajar }}{\sum \text { Siswa }} \times 100 \%
$$


HASIL

Data observasi berupa pengamatan pengelolaan metode Pemanfaatan proyektor di labolatorium computer dan pengamatan aktivitas siswa dan guru pada akhir pembelajaran, data tes formatif dan tes unjuk kerja siswa pada setiap siklus. Data hasil uji coba item butir soal digunakan untuk mendapatkan tes yang bisa dipakai untuk acuan skor pada tes unjuk kerja. Data ini selanjutnya dianalisis taraf kesukarannya .

Data lembar observasi diambil dari dua pengamatan yaitu data pengamatan pengelolaan metode Pemanfaatan proyektor yang digunakan untuk mengetahui pengaruhnya dalam meningkatkan prestasi belajar siswa dan data pengamatan aktivitas siswa dan guru. Data tes formatif dan unjuk kerja untuk mengetahui peningkatan prestasi belajar siswa setelah diterapkan metode Pemanfaatan proyektor

\section{Analisis Data Penelitian Persiklus}

\section{Siklus I}

a. Tahap Perencanaan

Pada tahap ini peneliti mempersiapkan perangkat pembelajaran yang terdiri dari rencana pelajaran 1 , soal tes formatif 1 dan alat-alat pengajaran yang mendukung.

b. Tahap Kegiatan dan Pelaksanaan

Pelaksanaan kegiatan belajar mengajar untuk siklus I dilaksanakan pada tanggal 9 Januari 2020 di Kelas VIII D dengan jumlah siswa 20 siswa.Dalam hal ini peneliti bertindak sebagai guru. Adapun proses belajar mengajar mengacu pada rencana pelajaran yang telah dipersiapkan. Pengamatan (observasi) dilaksanakan bersamaan dengan pelaksaaan belajar mengajar. Pada akhir proses belajar mengajar siswa diberi tes Unjuk kerja dan tes obyetif ( tes yang menjelaskan langah langkah pada tes unjuk kerja secara tertulis) dengan tujuan untuk mengetahui tingkat keberhasilan siswa dalam proses belajar mengajar yang telah dilakukan. Adapun data hasil penelitian pada siklus I adalah sebagai berikut:

Tabel 4.1. Rekapitulasi Hasil Tes obyektif Siswa pada Siklus 1

\begin{tabular}{lll}
\hline No & Uraian & Hasil Siklus I \\
\hline 1 & Nilai rata-rata tes formatif & 62,91 \\
2 & Jumlah siswa yang tuntas belajar & 11 \\
3 & Persentase Siswa Tuntas belajar & $55 \%$ \\
\hline
\end{tabular}

Dari tabel di atas dapat dijelaskan bahwa dengan pengajaran menggunakanMedia Proyektor diperoleh nilai rata-rata prestasi belajar siswa adalah 62,91 dan ketuntasan belajar mencapai 55\% atau ada 11 siswa dari 20 siswa sudah tuntas belajar. Hasil tersebut menunjukkan bahwa pada siklus pertama secara klasikal siswa belum tuntas belajar, karena siswa yang memperoleh nilai $\geq 68$ hanya sebesar $55 \%$ lebih kecil dari persentase ketuntasan yang dikehendaki yaitu sebesar $85 \%$. Hal ini disebabkan karena siswa masih asing dengan diterapkannya pembelajaran dengan pemanfaatan media proyektor. 
KARANGAN: Jurnal Kependidikan, Pembelajaran, dan Pengembangan, Vol 02, No 01, Bln Feb, Tahun 2020, Hal 21 - 31

\section{Siklus II}

a. Tahap perencanaan

Pada tahap ini peneliti mempersiapkan perangkat pembelajaran yang terdiri dari rencana pelajaran 2, soal tes Unjuk kerja dan obyektif II dan alatalat pengajaran yang mendukung.

b. Tahap kegiatan dan pelaksanaan

Pelaksanaan kegiatan belajar mengajar untuk siklus II dilaksanakan pada tanggal 16 Januari 2020 di Kelas VIII D SMP Negeri 1 Sekaran dengan jumlah siswa 20 siswa. Dalam hal ini peneliti bertindak sebagai guru. Adapun proses belajar mengajar mengacu pada rencana pelajaran dengan memperhakan revisi pada siklus I, sehingga kesalahan atau kekurangan pada siklus I tidak terulang lagi pada siklus II. Pengamatan (observasi) dilaksanakan bersamaan dengan pelaksanaan belajar mengajar. Pada akhir proses belajar mengajar siswa diberi tes formatif ( obyektif) dan unjuk kerja II dengan tujuan untuk mengetahui tingkat keberhasilan siswa dalam proses belajar mengajar yang telah dilakukan. Instrument yang digunakan adalah tes formatif dan unjuk kerja II.Adapun data hasil penelitian pada siklus II adalah sebagai berikut.

Tabel 4.2. Hasil Tes Formatif (obyektif) dan unjuk kerja Siswa pada Siklus II

\begin{tabular}{lll} 
No & Uraian & Hasil Siklus II \\
\hline 1 & Nilai rata-rata tes & 70,91 \\
2 & Jumlah siswa yang tuntas belajar & 14 \\
3 & Persentase Siswa Tuntas belajar & $70 \%$ \\
\hline
\end{tabular}

Dari tabel di atas diperoleh nilai rata-rata prestasi belajar siswa adalah 70,91 dan ketuntasan belajar mencapai $70 \%$ atau ada 14 siswa dari 20 siswa sudah tuntas belajar. Hasil ini menunjukkan bahwa pada siklus II ini ketuntasan belajar secara klasikal telah mengalami peningkatan yang signifikan lebih baik dari siklusI. Adanya peningkatan hasil belajar siswa ini karena siswa sudah mulai akrab dan menemuan keasyikan dengan metode pembelajaran Pemanfaatan proyektor. Disamping itu kemampuan guru dalam mengelola proses belajar mengajar dalam metode ini juga semakin meningkat sehingga proses belalar-mengajar semakin efektif.

\section{Siklus III}

a. Tahap Perencanaan

Pada tahap ini peneliti mempersiapkan perangkat pembelajaran yang terdiri dari rencana pelajaran 3, soal tes formatif ( Obyetif dan unjuk kerja) dan alat-alat pengajaran yang mendukung.

b. Tahap kegiatan dan pengamatan

Pelaksanaan kegiatan belajar mengajar untuk siklus III dilaksanakan pada tanggal 23 Januari 2020 pada Kelas VIII D SMP Negeri 1 Sekaran dengan jumlah siswa 20 siswa. Dalam hal ini peneliti bertindak sebagai guru. Adapun proses belajar mengajar mengacu pada rencana pelajaran dengan memperhakan revisi pada siklus II, sehingga kesalahan atau kekurangan pada siklus II tidak terulang lagi pada siklus III. Pengamatan (observasi) dilaksanakan bersamaan dengan pelaksanaan belajar mengajar. Pada akhir proses belajar mengajar siswa diberi tes formatif (Obyektif dan unjuk kerja) III dengan tujuan untuk mengetahui tingkat keberhasilan siswa dalam proses belajar mengajar yang telah dilakukan. Instrumen yang digunakan adalah tes 
formatif (obyektif dan unjuk kerja) III. Adapun data hasil penelitian pada siklus III adalah sebagai berikut:

Tabel 4.3. Hasil Tes pada Siklus III

\begin{tabular}{lll}
\hline No & Uraian & Hasil Siklus III \\
\hline 1 & Nilai rata-rata tes & 75,04 \\
2 & Jumlah siswa yang tuntas belajar & 18 \\
3 & Persentase ketuntasan belajar & $90 \%$ \\
\hline
\end{tabular}

Berdasarkan tabel diatas diperoleh nilai rata-rata tes formatif sebesar 75,04 dan dari 20 siswa yang telah tuntas sebanyak 18 siswa dan 2 siswa belum mencapai ketuntasan belajar. Maka secara klasikal ketuntasan belajar yang telah tercapai sebesar $90 \%$ (termasuk kategori tuntas).Hasil pada siklus III ini mengalami peningkatan lebih baik dari siklus II.Adanya peningkatan hasil belajar pada siklus III ini dipengaruhi oleh adanya peningkatan kemampuan siswa mempelajari materi pelajaran yang telah diterapkan selama ini. Disamping itu dengan adanya metode pembelajaran ini siswa dapat bertanya dengan sesama temanya, dan ternyata dari proses bertanya antar siswa ini, siswa lebih mudah menerima penjelasan dari temannya yang lebih paham tengtang materi pelejaran tersebut. Juga dari hasil pembelajaran kontekstual model pengajaran berbasis masalah ini murid jadi lebih mudah untuk bekerja sama dengan sesama temanya.

c. Refleksi

Pada tahap ini akan dikaji apa yang telah terlaksana dengan baik maupun yang masih kurang baik dalam proses belajar mengajar dengan penerapan Pemanfaatanmedia proyektor . Dari data-data yang telah diperoleh dapat duraikan sebagai berikut: Selama proses belajar mengajar guru telah melaksanakan semua pembelajaran dengan baik. Meskipun ada beberapa aspek yang belum sempurna, tetapi persentase pelaksanaannya untuk masingmasing aspek cukup besar. Berdasarkan data hasil pengamatan diketahui bahwa siswa aktif selama proses belajar berlangsung. Kekurangan pada siklussiklus sebelumnya sudah mengalami perbaikan dan peningkatan sehingga menjadi lebih baik. Hasil belajar siswsa pada siklus III mencapai ketuntasan.

\section{d. Revisi Pelaksanaan}

Pada siklus III guru telah menerapkan Pemanfaatanmedia proyektor dengan baik dan dilihat dari aktivitas siswa serta hasil belajar siswa pelaksanaan proses belajar mengajar sudah berjalan dengan baik. Maka tidak diperlukan revisi terlalu banyak, tetapi yang perlu diperhatikan untuk tindakah selanjutnya adalah memaksimalkan dan mempertahankan apa yang telah ada dengan tujuan agar pada pelaksanaan proses belajar mengajar selanjutnya penerapan metode pembelajaran kontekstual model pengajaran berbasis masalah dapat meningkatkan proses belajar mengajar sehingga tujuan pembelajaran dapat tercapai. 
KARANGAN: Jurnal Kependidikan, Pembelajaran, dan Pengembangan, Vol 02, No 01, Bln Feb, Tahun 2020, Hal 21 - 31

\section{Pembahasan}

Ketuntasan Hasil Belajar Siswa

Gambar 1: Ketuntas Hasil Belajar

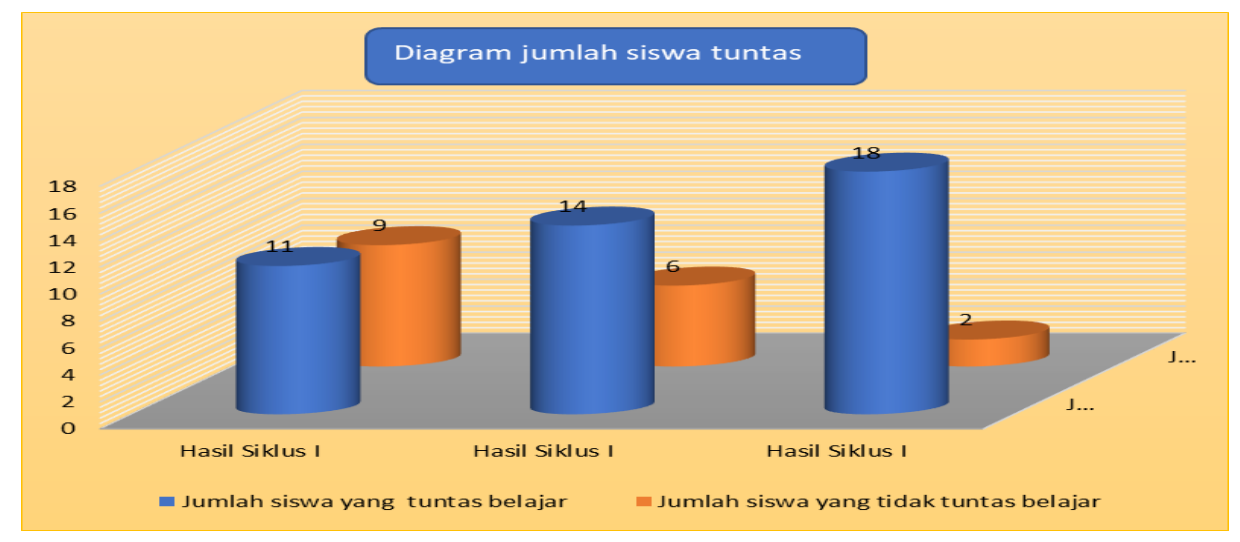

Gambar 2: Rata-rata Persentase Ketuntasan Siswa

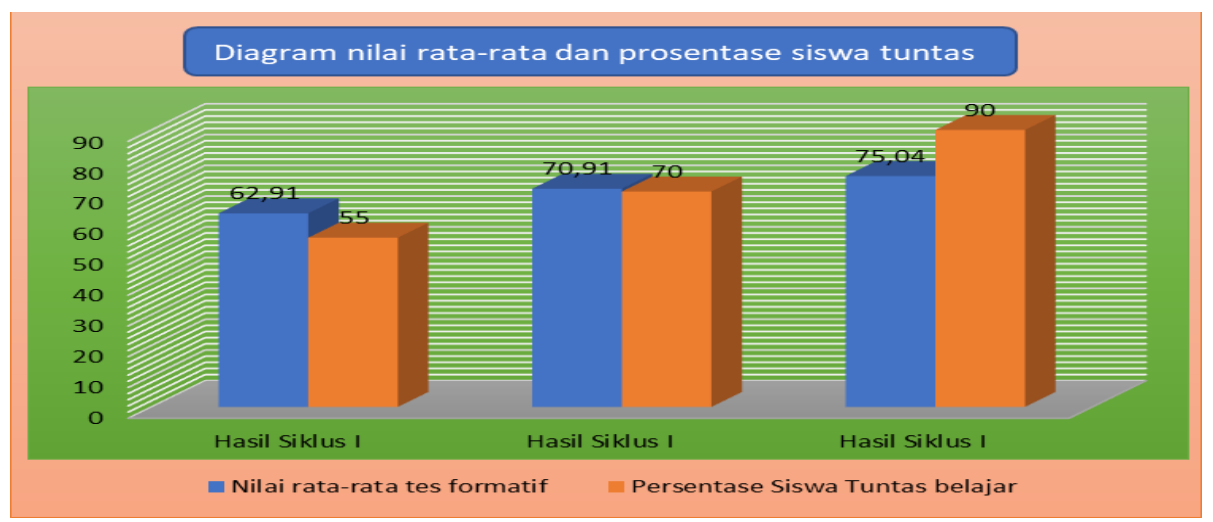

Melalui hasil peneilitian ini yang ditunjukkan oleh diagram di atas (gambar 4.1 dan 4.2) bahwa pembelajaran dengan pemanfaatan proyektor memiliki dampak positif dalam meningkatkan daya ingat siswa. Hal ini dapat dilihat dari semakin meningatkan pemahaman dan penguasaan siswa terhadap materi yang telah disampaikan guru selama ini (ketuntasan belajar meningkat dari siklus I, II, dan III) yaitu masing-masing $55 \%$, $70 \%$, dan $90 \%$.Pada siklus III ketuntasan belajar siswa secara klasikal telah tercapai.

\section{Kemampuan Guru dalam Mengelola Pembelajaran}

Berdasarkan analisis data, diperoleh aktivitas siswa dalam proses pembelajaran kontekstual model pengajaran berbasis masalah dalam setiap siklus mengalami peningkatan. Hal ini berdampak positif terhadap proses mengingat kembali materi pelajaran yang telah diterima selama ini, yaitu dapat ditunjukkan dengan meningkatnya nilai rata-rata siswa pada setiap siklus yang terus mengalami peningkatan. 


\section{Aktivitas Guru dan Siswa Dalam Pembelajaran}

Berdasarkan analisis data, diperoleh aktivitas siswa dalam proses pembelajaran BK-TIK /Informatika dengan media proyektor yang paling dominan adalah bekerja dengan menggunakan alat/media, mendengarkan/memperhatikan penjelasan guru melalui media proyektor, dan diskusi antar siswa/antara siswa dengan guru. Jadi dapat dikatakan bahwa aktivitas siswa dapat dikategorikan aktif.

Sedangkan untuk aktivitas guru selama pembelajaran telah melaksanakan langkah-langkah metode pembelajaran yang menerapkan media proyektor dengan baik.Hal ini terlihat dari aktivitas guru yang muncul di antaranya aktivitas membimbing dan mengamati siswa dalam mengerjakan kegiatan, menjelaskan/melatih menggunakan alat, memberi umpan balik/evaluasi/tanya jawab dimana prosentase untuk aktivitas di atas cukup besar.

\section{SIMPULAN DAN SARAN}

\section{Simpulan}

Dari hasil kegiatan pembelajaran yang telah dilakukan selama tiga siklus, dan berdasarkan seluruh pembahasan serta analisis yang telah dilakukan dapat disimpulkan sebagai berikut:

1. Pembelajaran dengan pembelajaran dengan Pemanfaatan media proyektor memiliki dampak positif dalam meningkatkan prestasi belajar siswa yang ditandai dengan peningkatan ketuntasan belajar siswa dalam setiap siklus, yaitu siklus I (55\%), siklus II (70 \%), siklus III (90\%).

2. Penerapan pembelajaran dengan Pemanfaatan media proyektor mempunyai pengaruh positif, yaitu dapat meningkatkan motivasi belajar siswa untuk mempelajari materi pelajaran yang diterima selama ini, dimana hal tersebut ditunjukan dengan rata-rata sikap siswa yang menyatakan bahwa siswa tertarik dan berminat dengan Pemanfaatan media proyektor sehingga mereka menjadi termotivasi untuk belajar.

3. Pembelajaran dengan Pemanfaatan media proyektor memiliki dampak positif terhadap pemahaman materi pelajaran yang diajarkan, dimana dengan metode ini siswa merasa senang dan tertantang dengan materi palajaran yang diajarkan.

\section{Saran}

Dari hasil penelitian yang diperoleh dari uraian sebelumnya agar proses belajar mengajar BK-TIK / Informatika lebih efektif , menyenangkan dan lebih memberikan hasil yang optimal bagi siswa, maka disampaikan saran sebagai berikut:

1. Untuk melaksanakan metode pembelajaran dengan Pemanfaatan media proyektor memerlukan persiapan yang cukup matang, sehingga guru harus mempu menentukan atau memilih topik yang benar-benar bisa diterapkan dengan metode ini dalam proses belajar mengajar sehingga diperoleh hasil yang optimal.

2. Dalam rangka meningkatkan prestasi belajar siswa, guru hendaknya lebih sering melatih siswa dengan berbagai metode pengajaran yang sesuai, walau dalam taraf yang sederhana, dimana siswa nantinya dapat menemuan pengetahuan baru, memperoleh konsep dan keterampilan, sehingga siswa berhasil atau mampu memecahkan masalah-masalah yang dihadapinya.

3. Perlu adanya penelitian yang lebih lanjut, karena hasil penelitian ini hanya dilakukan pada kelas VIII D Smp Negeri 1 Sekaran. Tahun Pelajaran 2019/2020 
KARANGAN: Jurnal Kependidikan, Pembelajaran, dan Pengembangan, Vol 02, No 01, Bln Feb, Tahun 2020, Hal 21 - 31

\section{DAFTAR RUJUKAN}

Arikunto, Suharsimi. 2002. Prosedur Penelitian Suatu Pendekatan Praktek. Jakarta: Rineksa Cipta

Ali, Muhammad. 1996. Guru Dalam Proses Belajar Mengajar.Bandung: Sinar Baru Algesindon.

Daroeso, Bambang. 1989. Dasar dan Konsep Pendidikan Moral Pancasila. Semarang: Aneka Ilmu.

Dayan, Anto. 1972. Pengantar Metode Statistika Deskriptif, tt. Lembaga Penelitian Pendidian dan Penerangan Ekonomi.

Hadi, Sutrisno. 198. Metodologi Research, Jilid 1. Yogyakarta: YP. Fak. Psikologi UGM.

Melvin, L. Siberman. 2004. Aktif Learning, 101 Cara Belajar Siswa Aktif. Bandung: Nusamedia dan Nuansa.

Ngalim, Purwanto M. 1990. Psikologi Pendidikan. Bandung: PT. Remaja Rosdakarya.

Riduwan.2000. Belajar Mudah Penelitian untuk Guru-Karyawan dan Peneliti Pemula.Bandung: Alfabeta.

Sukmadinata, Nana Syaodih. 2000. Metode Penelitian Pendidikan. Bandung: PT. Remaja Rosdakarya.

Surakhmad, Winarno. 1990. Metode Pengajaran Nasional.Bandung: Jemmars. 